\title{
PENERAPAN NAIVE BAYES GAUSSIAN PADA KLASIFIKASI JENIS JAMUR BERDASARKAN CIRI STATISTIK ORDE PERTAMA
}

\author{
Arma Adzhana Mahran ${ }^{1)}$, Rinci Kembang Hapsari ${ }^{2)}$, Hendro Nugroho ${ }^{3)}$ \\ 1), 2),3) Teknik Informatika. Fakultas Teknik Elektro dan Teknologi Informasi, Institut Teknologi Adhi \\ Tama Surabaya \\ Email :stichharma@gmail.com ${ }^{1)}$, rincikembang@itats.ac.id ${ }^{2}$, hendro@itats.ac.id $^{3)}$
}

\begin{abstract}
Abstrak
Fungi atau jamur merupakan tumbuhan yang tidak mempunyai klorofil sehingga bersifat heterotrof, tipe sel eukarotik. Jamur ada yang uniseluler dan multiseluler. Jenis jamur ada yang bisa dikonsumsi dan ada yang tidak bisa dikonsumsi. Pengenalan tipe jamur secara digital merupakan pendekatan yang mungkin dilakukan untuk memberikan informasi kepada masyarakat atau publik yang ingin mengetahui jamur mana yang aman untuk dikonsumsi dan yang tidak.Pada penelitian ini dilakukan klasifikasi jenis jamur dengan menggunakan input citra jamur. Langkah klasifikasi jenis jamur yang dilakukan dalam penelitian ini terdiri dari tiga langkah. Langkah pertama, yaitu Image Pre Processing, dilakukan dengan mengkonversi citra $R G B$ ke grayscale dan membuat grafik histogramnya. Langkah kedua yaitu Ektraksi Fitur, dilakukan dengan mengimplementasikan metode statistic orde 1. Pada penelitian ini menggunakan metode statistic orde 1 dengan 5 parameter, yaitu mean, skewness, variance, kurtosis, dan entropy. Dan langkah ketiga, melakukan Klasifikasi dengan menggunakan metode Nä̈ve Bayes Gaussian. Hasil pengujian terhadap 60 citra jamur yang telah dilakukan dengan metode cross validation dengan nikai $k=4$ didapatkan nilai akurasi sebesar $98.75 \%$
\end{abstract}

Kata kunci: $\quad$ Ekstraksi Ciri Statistik Orde Pertama, Naive Bayes Gaussian, Cross Validation

\begin{abstract}
Fungal or mushroom are plants that do not have chlorophyll so they are heterotrophic, eukarotic cell types. Fungal are the unicellular and multicellular. There are types of mushrooms that can be consumed and some that can not be consumed. Digital recognition of mushroom types is a possible approach to provide information to the public or public who want to know which mushrooms are safe for consumption and which are not. The step in the classification of the types of mushrooms in this study consists of three steps. The first step, Image Pre Processing, is done by converting an RGB image to grayscale and creating a histogram graphic. The second step is Feature Extraction, which is carried out by implementing the 1st order statistical method. This research uses the 1st order statistical method with 5 parameters, namely the mean, skewness, variance, kurtosis, and entropy. And the third step is to perform classification using the Naïve Bayes Gaussian method. The results of testing on 60 mushroom images that have been carried out by the cross validation method with nikai $k=4$ obtained an accuracy value of $98.75 \%$
\end{abstract}

Keywords : First Order Statistical Feature Extraction, Naive Bayes Gaussian, Cross Validation

\section{PENDAHULUAN}

Fungi atau jamur merupakan tumbuhan yang tidak mempunyai klorofil sehingga bersifat heterotrof, tipe sel eukarotik. Jamur ada yang uniseluler dan multiseluler. Tubuhnya terdiri dari benang-benang yang disebut hifa yang dapat membentuk anyaman bercabang-cabang (miselium). Organisme yang disebut jamur bersifat heterotrof, dinding sel spora mengandung kitin, tidak berplastid, tidak berfotosintesis, tidak bersifat fagotrof, umumnya memiliki hifa yang berdinding yang dapat berinti banyak (multinukleat), atau berinti tunggal (mononukleat), dan memperoleh nutrien dengan cara absorpsi [1].

Pengenalan tipe jamur secara digital merupakan pendekatan yang mungkin dilakukan untuk memberikan informasi kepada masyarakat atau publik yang ingin mengetahui jamur mana yang aman untuk dikonsumsi dan yang tidak. Identifikasi jamur bertujuan untuk melakukan 
pengamatan dan analisa untuk melihat sejauh mana algoritma klasifikasi naive bayes gaussian dapat membedakan jenis-jenis jamur [1].

Pengenalan pola merupakan suatu hal yang mudah dilakukan oleh manusia, namun tidak demikian bagi sebuah mesin atau komputer. Seseorang dapat dengan mudah mengenali jenis jamur berdasarkan bentuk atau warna. Namun, tidak demikian bagi sebuah mesin atau komputer yang belum dilengkapi dengan sistem yang cerdas. Sehingga adanya kemiripan dan perbedaan antara jenis jamur dapat menjadi ide untuk dikembangkan menjadi sebuah penelitian baru [2] [3].

Ekstraksi ciri bertujuan untuk menajamkan perbedaan-perbedaan pola sehingga akan sangat memu-dahkan dalam pemisahan kategori klas pada proses klasifikasi. Metode identifikasi citra jamur sangat beragam, salah satunya proses identifikasi citra jamur dengan ekstraksi ciri Statistik orde 1. Ekstraksi ciri Statistik orde 1 merupakan metode pengambilan ciri yang didasarkan pada karakteristik histogram citra. Histogram menunjukkan probabilitas kemunculan nilai derajat keabuan piksel pada suatu citra. Dari nilai-nilai pada histogram yang dihasilkan, dapat dihitung beberapa parameter ciri Statistik orde 1, antara lain adalah mean (rata-rata), skewness, variance, kurtosis dan entropy [4].

Klasifikasi Bayes didasarkan pada teorema Bayes untuk probabilitas bersyarat. Teorema ini mengkuantifikasi probabilitas bersyarat dari variabel acak (variabel kelas), memberikan pengamatan yang diketahui tentang nilai set variabel acak lainnya (variabel fitur). Teorema Bayes digunakan secara luas dalam probabilitas dan statistik [5]. Algoritma Naïve Bayes Gaussian berbeda dengan algoritma Naïve Bayes. Perbedaannya adalah algoritma Naïve Bayes Gaussian memiliki distribusi Gaussian.

Berdasarkan penelitian yang dilakukan oleh Gustina, Abdul, \& Rusyidi pada tahun 2017 dengan judul "Sistem Identifikasi Jamur Menggunakan Metode Ekstraksi Ciri Statistik Orde Pertama dan Klasifikasi Jarak" didapatkan akurasi tertinggi mencapai 82\%. Dalam klasifikasi jamur menggunakan ekstraksi ciri statistik orde pertama dan klasifikasi jarak yang terbaik adalah menggunakan klasifikasi jarak Manhattan [6].

Dalam penelitian ini diterapkan metode fitur ektraksi ciri statistik orde pertama untuk mendapatkan fitur citra yang kemudian akan digunakan algoritma klasifikasi Naive Bayes Gaussian untuk mengidentifikasi jenis jamur.

\section{DASAR TEORI}

\section{a. Citra Grayscale}

Citra grayscale adalah citra digital yang hanya mempunyai satu nilai kanal pada setiap pikselnya, dengan kata lain nilai bagian red $=$ green $=$ blue. Citra grayscale memiliki kedalaman warna 8 bit (256 kombinasi warna abu-abu [7] [8].

\section{b. Histogram Warna}

Histogram warna atau color histogram adalah representasi distribusi warna dalam sebuah gambar yang didapatkan dengan menghitung jumlah pixel dari setiap bagian range warna, secara tipikal dalam dua dimensi atau tiga dimensi. Dalam pembuatan histogram, nilai RGB mempunyai range dari 0 sampai 255 akan punya kemungkinan kombinasi warna sebesar 16777216 (didapat dari: 255 x 255 x 255) [7] [9].

\section{c. Ekstraksi Fitur}

Ektraksi fitur merupakan tahapan mengekstrak ciri atau informasi yang dimiliki oleh suatu objek dalam citra. Ciri atau informasi tersebut dapat digunakan untuk membedakan antara objek yang satu dengan objek lainnya.

Ektraksi fitur dilakukan dengan cara menghitung jumlah titik atau pixels yang ditemui dalam setiap pengecekan, dimana pengecekan dilakukan dalam berbagai arah tracing pengecekan pada koordinat kartesian dari citra digital yang dianalisis, yaitu vertikal, horizontal, diagonal kanan, dan diagonal kiri.

\section{d. Ekstraksi Ciri Statistik}


Analisis tekstur lazim dimanfaatkan sebagai proses antara untuk melakukan klasifikasi dan interpretasi citra. Suatu proses klasifikasi citra berbasis analisa tekstur pada umumnya membutuhkan proses ekstraksi ciri, yang terdiri dalam tiga macam metode berikut:

\section{Metode Statistik}

Metode statistik menggunakan persamaan statistik distribusi derajat keabuan (histogram) dengan mengukur tingkat kekontrasan, granularitas, dan kekasaran suatu daerah dari hubungan ketetanggaan antar piksel di dalam citra. Paradigma dari statistik ini penggunaannya tidak terbatas, sehingga sesuai untuk tekstur tekstur alami yang tidak terstruktur dari sub pola dan himpunan aturan (mikrostruktur).

\section{Metode Spektral}

Metode spektral berdasarkan pada fungsi autokorelasi suatu daerah atau power distribution pada domain transformasi Fourier dalam mendeteksi periodisitas tekstur.

\section{e. Klasifikasi}

Masalah klasifikasi terkait erat dengan masalah pengelompokan. Sementara masalah pengelompokan adalah penentuan kelompok-kelompok data yang serupa, masalah klasifikasi adalah mempelajari struktur kumpulan data contoh, sudah dipartisi menjadi kelompok-kelompok, yang disebut sebagai kategori atau kelas. Pembelajaran kategori ini biasanya dicapai dengan model. Model ini digunakan untuk memperkirakan pengenal kelompok (atau label kelas) dari satu atau beberapa contoh data yang sebelumnya tidak terlihat dengan label yang tidak dikenal. Oleh karena itu, salah satu masukan untuk masalah klasifikasi adalah contoh kumpulan data yang telah dipartisi ke dalam kelas yang berbeda. Ini disebut sebagai data pelatihan, dan pengidentifikasi kelompok kelas-kelas ini disebut sebagai label kelas.

Dalam banyak kasus, label kelas memiliki interpretasi semantik yang jelas dalam konteks aplikasi tertentu, seperti sekelompok pelanggan yang tertarik pada produk tertentu, atau sekelompok objek data dengan properti yang diinginkan. Model yang dipelajari disebut sebagai model pelatihan. Titik data yang sebelumnya tidak terlihat yang perlu diklasifikasikan secara kolektif disebut sebagai kumpulan data uji. Algoritma yang menciptakan model pelatihan untuk prediksi juga kadang-kadang disebut sebagai pelajar [5] [10].

\section{f. Cross Validation}

Cross-validation $(\mathrm{CV})$ sering digunakan untuk memperkirakan kemampuan generalisasi model pembelajaran. Varians kesalahan CV memiliki dampak yang cukup besar pada keakuratan penduga $\mathrm{CV}$ dan kecukupan model pembelajaran, sehingga sangat penting untuk menganalisis varian CV. Tujuan dari makalah ini adalah untuk menyelidiki bagaimana meningkatkan akurasi estimasi kesalahan berdasarkan analisis varians. Kami pertama kali menggambarkan hubungan kuantitatif antara varians CV dan akurasinya, yang dapat memberikan panduan untuk meningkatkan akurasi dengan mengurangi varians.

Kami kemudian mempelajari hubungan antara varians dan variabel yang relevan termasuk ukuran sampel, jumlah lipatan, dan jumlah pengulangan. Ini membentuk dasar strategi teoritis untuk mengatur varian CV. Hasil klasifikasi kami secara teoritis dapat menjelaskan hasil empiris dari Rodr'iguez dan Kohavi. Akhirnya, kami mengusulkan varian normalisasi seragam yang tidak hanya mengukur akurasi model tetapi juga tidak relevan dengan jumlah lipatan. Oleh karena itu, ini menyederhanakan pemilihan nomor lipatan dalam k-fold CV dan varians yang dinormalisasi dapat berfungsi sebagai pengukuran kesalahan yang stabil untuk perbandingan dan pemilihan model. Kami melaporkan hasil percobaan menggunakan 5 model pembelajaran terawasi dan 20 dataset. Hasil menunjukkan bahwa itu dapat diandalkan untuk menentukan varians mana yang kurang sebelum k-fold $\mathrm{CV}$ oleh teorema yang diusulkan, dan dengan demikian akurasi estimasi kesalahan dapat dipromosikan dengan mengurangi varians. Dengan demikian, kita cenderung memilih [11].

\section{g. Akurasi}

Evaluasi hasil klasifikasi dilakukan dengan mengukur akurasi metode. Akurasi atau rasio data yang diklasifikasikan dengan benar terhadap semua data yang tersedia dapat dihitung sebagai berikut [12]: 
(1)

$$
\text { Akurasi }=\frac{T P+T N}{(T P+T N+F P+F N)} * 100 \%
$$

Dimana :
$\mathrm{TP}=$ True Positif;
$\mathrm{TN}=$ True Negatif
FP $=$ False Positif
$\mathrm{TN}=$ True Negatif

\section{METODOLOGI PENELITIAN}

Desain alur sistem klasifikasi jenis jamur pada penelitian ini, dimulai dari input data, image pre-processing, feature extraction menggunakan statistic orde 1, klasifikasi menggunakan Nä̈ve Beyes Gaussian, dan output identifikasi jenis ditunjukkan pada Gambar 1.

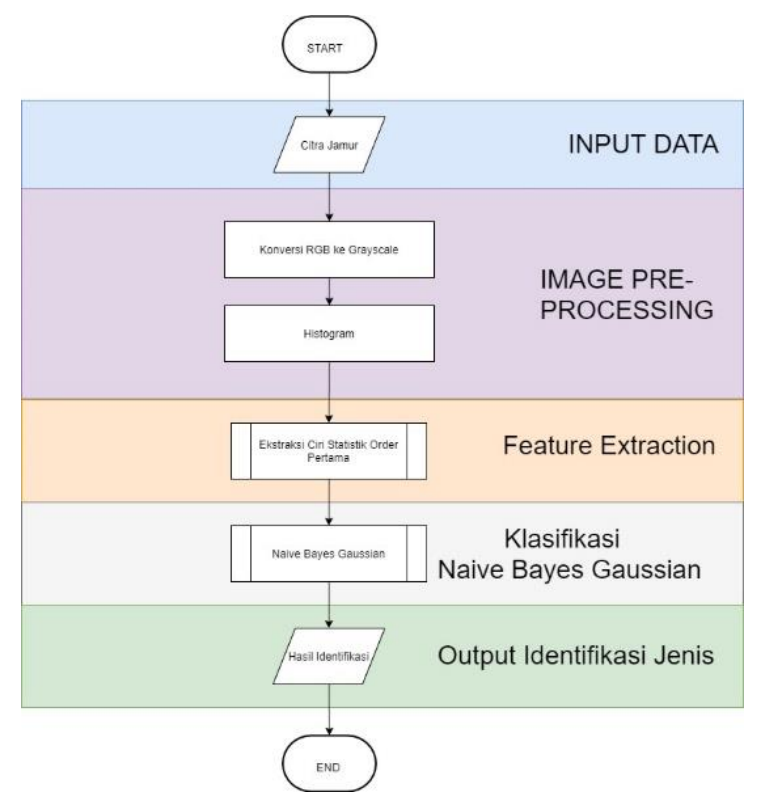

\section{a. Ekstraksi Ciri Statistik Order Pertama}

Gambar 1. Flowchart Sistem klasifikasi jenis jamur

Ekstraksi ciri orde pertama merupakan metode pengambilan ciri yang didasarkan pada karakteristik histogram citra. Histogram menunjukkan probabilitas kemunculan nilai derajat keabuan piksel pada suatu citra. Dari nilai-nilai pada histogram yang dihasilkan, dapat dihitung beberapa parameter ciri orde pertama, antara lain adalah mean, skewness, variance, kurtosis, dan entropy [13].

\section{Mean $(\mu)$}

Dimana :

$$
\mu=\sum_{\mathrm{n}} \mathrm{f}_{\mathrm{n}} \mathrm{p}\left(\mathrm{f}_{\mathrm{n}}\right)
$$

$f_{n}=$ Nilai intensitas keabuan.

$p\left(f_{n}\right)=$ Probabilitas kemunculan nilai intensitas tersebut.

2. Variance $\left(\sigma^{2}\right)$

Dimana :

$$
\sigma^{2}=\sum_{n}\left(f_{n}-\mu\right)^{2} p\left(f_{n}\right)
$$

$f_{n}=$ Nilai intensitas keabuan.

$p\left(f_{n}\right)=$ Probabilitas kemunculan nilai intensitas tersebut.

$\mu=$ Mean

3. Skewness $\left(\alpha_{3}\right)$

Dimana :

$$
\alpha_{3}=\frac{1}{\sigma^{3}} \sum_{n}\left(f_{n}-\mu\right)^{3} p\left(f_{n}\right)
$$

$$
f_{n}=\text { Nilai intensitas keabuan. }
$$


$p\left(f_{n}\right)=$ Probabilitas kemunculan nilai intensitas tersebut. $\mu=$ Mean

4. Kurtosis $\left(\alpha_{4}\right)$

$$
\alpha_{4}=\frac{1}{\sigma^{4}} \sum_{n}\left(f_{n}-\mu\right)^{4} p\left(f_{n}\right)-3
$$

Dimana :

$f_{n}=$ Nilai intensitas keabuan.

$p\left(f_{n}\right)=$ Probabilitas kemunculan nilai intensitas tersebut.

$\mu=$ Mean

$\sigma^{4}=$ Variance pangkat 2

5. Entropy $(H)$

Dimana :

$$
H=-\sum_{n} p\left(f_{n}\right) \cdot \log _{2} p\left(f_{n}\right)
$$

$p\left(f_{n}\right)=$ Probabilitas kemunculan nilai intensitas tersebut

\section{b. Naïve Bayes}

Klasifikasi yang dilakukan dalam penelitian ini menerapkan metode Naïve Bayes. Klasifikasi Bayes didasarkan pada teorema Bayes untuk probabilitas bersyarat. Teorema ini mengkuantifikasi probabilitas bersyarat dari variabel acak (variabel kelas), memberikan pengamatan yang diketahui tentang nilai set variabel acak lainnya (variabel fitur). Teorema Bayes digunakan secara luas dalam probabilitas dan statistik. Berikut ini adalah persamaan Nä̈ve Bayes [14]:

$$
\mathrm{V}_{\mathrm{nb}}=\operatorname{argmax}_{\mathrm{v}_{\mathrm{j} \in \mathrm{v}}} \mathrm{P}\left(\mathrm{v}_{\mathrm{j}}\right) \prod
$$

Persamaan untuk mencari $P\left(a_{i} \mid v_{j}\right)$ adalah sebagai berikut :

Dimana :

$$
\mathrm{P}\left(\mathrm{a}_{\mathrm{i}} \mid \mathrm{v}_{\mathrm{j}}\right)=\frac{\mathrm{n}_{\mathrm{c}}+\mathrm{mp}}{\mathrm{n}+\mathrm{m}}
$$

$\mathrm{n}=$ jumlah contoh training untuk $\mathrm{v}=v_{j}$

$n_{c}=$ sejumlah contoh untuk $\mathrm{v}=v_{j}$ dan $\mathrm{a}=a_{i}$

$\mathrm{p}=$ perkiraan apriori untuk $P\left(a_{i} \mid v_{j}\right)$

$\mathrm{m}=$ ukuran data sample yang ukurannya sama.

\section{HASIL DAN PEMBAHASAN}

a. Implementasi

Implementasi sistem yang dikembangkan berdasarkan desain sistem dengan menggunakan pemrograman Matlab. Pada Gambar 2a menunjukkan form untuk memilih citra input dan melakukan konversi citra RGB ke Grayscale.

Pada gambar 2b Menu Histogram RGB dan Histogram Grayscale, ketika button RGB ditekan maka akan dilakukan proses untuk menghitung Histogram Citra RGB yang kemudian hasilnya akan ditampilkan pada Axes Histogram Citra RGB. Selanjutkan ketika button Grayscale ditekan maka akan dilakukan proses untuk menghitung Histogram Citra Grayscale yang kemudian hasilnya akan ditampilkan pada Axes Histogram Citra Grayscale.

Pada Gambar 3a Menu Feature Extraction, ketika button Feature Extraction ditekan maka akan dilakukan proses untuk menghitung Feature Extraction dari citra Grayscale. Feature Extraction yang digunakan adalah ekstraksi ciri statistik orde pertama, dimana di dalam ekstraksi ciri statistik orde pertama terdapat lima parameter, yaitu Mean, Variance, Skewness, Kurtosis, dan Entropy. 


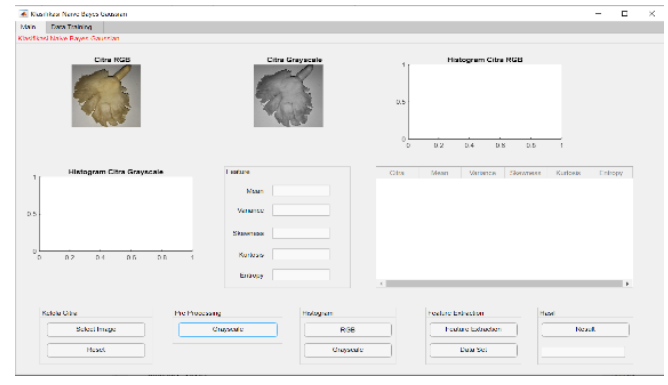

(a)

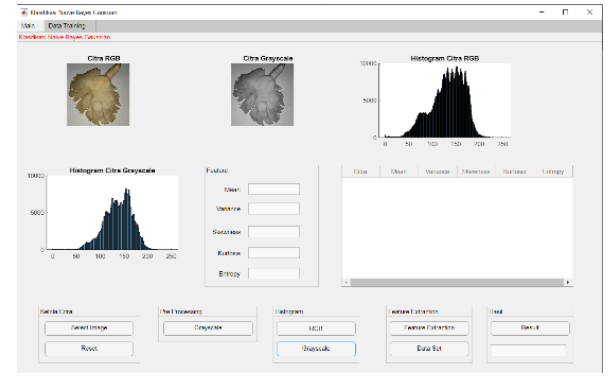

(b)

Gambar 2a. Tampilan Menu Pilih Citra dan Konversi RGB ke Grayscale Gambar 2b Tampilan Histogram RGB dan Histogram Grayscale.

Pada gambar 3b Menu Data Set, ketika button Data Set ditekan maka akan dilakukan proses untuk menampilkan data set yang berjumlah 240 citra yang sudah di ambil ciri atau fiturnya menggunakan algoritma feature extraction ekstraksi ciri statistic orde pertama dengan 5 parameter (mean, variance, skewness, kurtosis, entropy).

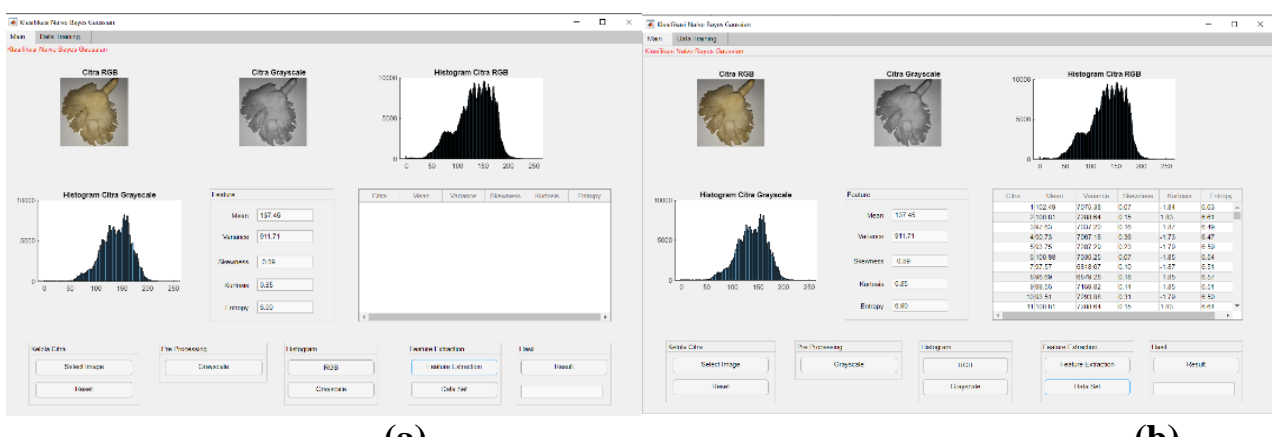

(a)

(b)

Gambar 3a Menu Feature Extraction. Gambar 4b. Menu Data Set.

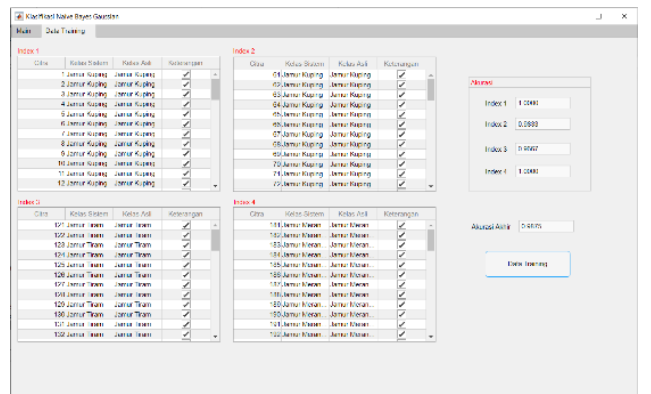

Gambar 4a Menu Klasifikasi Naive Bayes Gaussian.

Pada gambar 4a Menu Klasifikasi Nä̈ve Bayes Gaussian, ketika button Result ditekan maka akan dilakukan proses untuk menghitung proses klasifikasi naïve bayes gaussian yang kemudian hasilnya akan ditampilkan pada text field Hasil.

\section{b. Pengujian Sistem}

Pada tahap pengujian ini digunakan algoritma cross validation untuk mendapatkan nilai akurasinya. Nilai K yang digunakan adalah $K=4$ dari total citra berjumlah 240 , fungsi dari nilai $\mathrm{K}$ sendiri adalah untuk menjadi acuan partisi dataset. Hasil partisi dataset dimana $3 / 4$ bagian dijadikan sebegai data training dan $1 / 4$ bagian data set akan dijadikan sebagai data testing.

Pada skenario pengujian pertama data citra ke 1 - 60 dijadikan sebagai data testing dan citra ke 61-240 digunakan sebagai data training. Hasil pengujian dari skenario pengujian pertama ini ditunjukkan pada tabel 1. Hasil akurasi pada pengujian skenario 1 adalah $100 \%$. Pada skenario pengujian kedua, data citra ke 61-120 dijadikan sebagai data testing sedangkan data citra ke 1-60 dan data citra ke 121-240 digunakan sebagai data training. Pada skenario pengujian ini didapatkan akurasi $98,33 \%$. 
Tabel 1 Hasil pengujian skenario

\begin{tabular}{|c|c|c|c|c|c|c|c|}
\hline \multirow{2}{*}{ ID Citra } & \multicolumn{2}{|c|}{ Kelas } & \multirow{2}{*}{ Ketera-ngan } & \multirow{2}{*}{$\begin{array}{c}\text { ID } \\
\text { Citra }\end{array}$} & \multicolumn{2}{|c|}{ Kelas } & \multirow{2}{*}{$\begin{array}{c}\text { Ketera- } \\
\text { ngan }\end{array}$} \\
\hline & Sistem & Asli & & & Sistem & Asli & \\
\hline 1 & Jamur Kuping & Jamur Kuping & TRUE & 31 & $\begin{array}{c}\text { Jamur } \\
\text { Kuping }\end{array}$ & $\begin{array}{c}\text { Jamur } \\
\text { Kuping }\end{array}$ & TRUE \\
\hline 2 & Jamur Kuping & Jamur Kuping & TRUE & 32 & $\begin{array}{l}\text { Jamur } \\
\text { Kuping }\end{array}$ & $\begin{array}{l}\text { Jamur } \\
\text { Kuping }\end{array}$ & TRUE \\
\hline 3 & Jamur Kuping & Jamur Kuping & TRUE & 33 & $\begin{array}{l}\text { Jamur } \\
\text { Kuping }\end{array}$ & $\begin{array}{l}\text { Jamur } \\
\text { Kuping }\end{array}$ & TRUE \\
\hline 4 & Jamur Kuping & Jamur Kuping & TRUE & 34 & $\begin{array}{c}\text { Jamur } \\
\text { Kuping }\end{array}$ & $\begin{array}{c}\text { Jamur } \\
\text { Kuping }\end{array}$ & TRUE \\
\hline 5 & Jamur Kuping & Jamur Kuping & TRUE & 35 & $\begin{array}{c}\text { Jamur } \\
\text { Kuping }\end{array}$ & $\begin{array}{c}\text { Jamur } \\
\text { Kuping }\end{array}$ & TRUE \\
\hline 6 & Jamur Kuping & Jamur Kuping & TRUE & 36 & $\begin{array}{c}\text { Jamur } \\
\text { Kuping }\end{array}$ & $\begin{array}{l}\text { Jamur } \\
\text { Kuping }\end{array}$ & TRUE \\
\hline 7 & Jamur Kuping & Jamur Kuping & TRUE & 37 & $\begin{array}{c}\text { Jamur } \\
\text { Kuping }\end{array}$ & $\begin{array}{c}\text { Jamur } \\
\text { Kuping }\end{array}$ & TRUE \\
\hline 8 & Jamur Kuping & Jamur Kuping & TRUE & 38 & $\begin{array}{c}\text { Jamur } \\
\text { Kuping }\end{array}$ & $\begin{array}{c}\text { Jamur } \\
\text { Kuping }\end{array}$ & TRUE \\
\hline 9 & Jamur Kuping & Jamur Kuping & TRUE & 39 & $\begin{array}{c}\text { Jamur } \\
\text { Kuping }\end{array}$ & $\begin{array}{c}\text { Jamur } \\
\text { Kuping }\end{array}$ & TRUE \\
\hline 10 & Jamur Kuping & Jamur Kuping & TRUE & 40 & $\begin{array}{l}\text { Jamur } \\
\text { Kuping }\end{array}$ & $\begin{array}{l}\text { Jamur } \\
\text { Kuping }\end{array}$ & TRUE \\
\hline 11 & Jamur Kuping & Jamur Kuping & TRUE & 41 & $\begin{array}{l}\text { Jamur } \\
\text { Kuping }\end{array}$ & $\begin{array}{l}\text { Jamur } \\
\text { Kuping }\end{array}$ & TRUE \\
\hline 12 & Jamur Kuping & Jamur Kuping & TRUE & 42 & $\begin{array}{l}\text { Jamur } \\
\text { Kuping }\end{array}$ & $\begin{array}{l}\text { Jamur } \\
\text { Kuping }\end{array}$ & TRUE \\
\hline 13 & Jamur Kuping & Jamur Kuping & TRUE & 43 & $\begin{array}{l}\text { Jamur } \\
\text { Kuping }\end{array}$ & $\begin{array}{c}\text { Jamur } \\
\text { Kuping }\end{array}$ & TRUE \\
\hline 14 & Jamur Kuping & Jamur Kuping & TRUE & 44 & $\begin{array}{l}\text { Jamur } \\
\text { Kuping }\end{array}$ & $\begin{array}{l}\text { Jamur } \\
\text { Kuping }\end{array}$ & TRUE \\
\hline 15 & Jamur Kuping & Jamur Kuping & TRUE & 45 & $\begin{array}{c}\text { Jamur } \\
\text { Kuping }\end{array}$ & $\begin{array}{c}\text { Jamur } \\
\text { Kuping }\end{array}$ & TRUE \\
\hline 16 & Jamur Kuping & Jamur Kuping & TRUE & 46 & $\begin{array}{l}\text { Jamur } \\
\text { Kuping }\end{array}$ & $\begin{array}{c}\text { Jamur } \\
\text { Kuping }\end{array}$ & TRUE \\
\hline 17 & Jamur Kuping & Jamur Kuping & TRUE & 47 & $\begin{array}{l}\text { Jamur } \\
\text { Kuping }\end{array}$ & $\begin{array}{l}\text { Jamur } \\
\text { Kuping }\end{array}$ & TRUE \\
\hline 18 & Jamur Kuping & Jamur Kuping & TRUE & 48 & $\begin{array}{c}\text { Jamur } \\
\text { Kuping }\end{array}$ & $\begin{array}{c}\text { Jamur } \\
\text { Kuping }\end{array}$ & TRUE \\
\hline 19 & Jamur Kuping & Jamur Kuping & TRUE & 49 & $\begin{array}{c}\text { Jamur } \\
\text { Kuping }\end{array}$ & $\begin{array}{c}\text { Jamur } \\
\text { Kuping }\end{array}$ & TRUE \\
\hline 20 & Jamur Kuping & Jamur Kuping & TRUE & 50 & $\begin{array}{c}\text { Jamur } \\
\text { Kuping }\end{array}$ & $\begin{array}{l}\text { Jamur } \\
\text { Kuping }\end{array}$ & TRUE \\
\hline 21 & Jamur Kuping & Jamur Kuping & TRUE & 51 & $\begin{array}{l}\text { Jamur } \\
\text { Kuping }\end{array}$ & $\begin{array}{l}\text { Jamur } \\
\text { Kuping }\end{array}$ & TRUE \\
\hline 22 & Jamur Kuping & Jamur Kuping & TRUE & 52 & $\begin{array}{l}\text { Jamur } \\
\text { Kuping }\end{array}$ & $\begin{array}{c}\text { Jamur } \\
\text { Kuping }\end{array}$ & TRUE \\
\hline 23 & Jamur Kuping & Jamur Kuping & TRUE & 53 & $\begin{array}{l}\text { Jamur } \\
\text { Kuping }\end{array}$ & $\begin{array}{l}\text { Jamur } \\
\text { Kuping }\end{array}$ & TRUE \\
\hline 24 & Jamur Kuping & Jamur Kuping & TRUE & 54 & $\begin{array}{c}\text { Jamur } \\
\text { Kuping }\end{array}$ & $\begin{array}{l}\text { Jamur } \\
\text { Kuping }\end{array}$ & TRUE \\
\hline 25 & Jamur Kuping & Jamur Kuping & TRUE & 55 & $\begin{array}{c}\text { Jamur } \\
\text { Kuping }\end{array}$ & $\begin{array}{c}\text { Jamur } \\
\text { Kuping }\end{array}$ & TRUE \\
\hline
\end{tabular}




\begin{tabular}{|c|c|c|c|c|c|c|c|}
\hline \multirow{2}{*}{ ID Citra } & \multicolumn{2}{|c|}{ Kelas } & \multirow{2}{*}{ Ketera-ngan } & ID & \multicolumn{2}{c|}{ Kelas } & Ketera- \\
\cline { 6 - 7 } & Sistem & Asli & & Sistem & Asli & ngan \\
\hline 26 & Jamur Kuping & Jamur Kuping & TRUE & 56 & $\begin{array}{c}\text { Jamur } \\
\text { Kuping }\end{array}$ & $\begin{array}{c}\text { Jamur } \\
\text { Kuping }\end{array}$ & TRUE \\
\hline 27 & Jamur Kuping & Jamur Kuping & TRUE & 57 & $\begin{array}{c}\text { Jamur } \\
\text { Kuping }\end{array}$ & $\begin{array}{c}\text { Jamur } \\
\text { Kuping }\end{array}$ & TRUE \\
\hline 28 & Jamur Kuping & Jamur Kuping & TRUE & 58 & $\begin{array}{c}\text { Jamur } \\
\text { Kuping }\end{array}$ & $\begin{array}{c}\text { Jamur } \\
\text { Kuping }\end{array}$ & TRUE \\
\hline 29 & Jamur Kuping & Jamur Kuping & TRUE & 59 & $\begin{array}{c}\text { Jamur } \\
\text { Kuping }\end{array}$ & $\begin{array}{c}\text { Jamur } \\
\text { Kuping }\end{array}$ & TRUE \\
\hline 30 & Jamur Kuping & Jamur Kuping & TRUE & 60 & $\begin{array}{c}\text { Jamur } \\
\text { Kuping }\end{array}$ & $\begin{array}{c}\text { Jamur } \\
\text { Kuping }\end{array}$ & TRUE \\
\hline
\end{tabular}

Pada skenario pengujian ke tiga, data citra ke 121-180 dijadikan sebagai data testing sedangkan data citra ke 1-120 dan data citra ke 181-240 digunakan sebagai data training. Pada skenario pengujian ketiga ini didapatkan akurasi $96,67 \%$. Sedangkan pada skenario pengujian keempat, data citra ke 181-240 dijadikan sebagai data testing sedangkan data citra ke 1-180 digunakan sebagai data training. Pada skenario pengujian ketiga ini didapatkan akurasi $100 \%$. Berdasarkan keseluruhan pengujian didapatkan rata-rata akurasinya, yaitu :

$$
\text { rata }- \text { rata accuracy }=\frac{100 \%+98,33 \%+96,67 \%+100 \%}{4}=98,75 \%
$$

\section{KESIMPULAN}

Pada penelitian yang telah dilakukan dengan menggunakan algoritma Nä̈ve Bayes Gaussian untuk mengklasifikasi jenis jamur berdasarkan ciri statistik orde pertama dapat disimpulkan sebagai berikut:

1. Setelah dilakukan proses klasifikasi jenis jamur dengan jumlah citra sebesar 240 citra menggunakan metode naive bayes gaussian dan metode feature extraction ciri statistic orde pertama (mean, variance, skewness, kurtosis, entropy) dapat disimpulkan bahwa metode ini cocok untuk digunakan karena setelah dilakukan pengujian memiliki nilai akurasi yang tinggi

2. Dalam proses uji coba menggunakan metode cross validation dengan nikai $\mathrm{k}=60$ didapatkan nilai akurasi sebesar $98.75 \%$.

Berdasarkan dari penelitian yang telah dilakukan ini saran untuk perkembangan selanjutnya adalah sebagai berikut :

1. Pada tahap preprocessing perlu dicoba menggunakan teknik untuk memperbaiki kualitas citra seperti histogram equalization untuk melihat apakah akan menambah tingkat akurasi pada proses klasifikasinya atau tidak.

2. Pada tahap Feature Extraction perlu dicoba menggunakan algoritma feature extraction lain seperti GLCM, Thresholding, dan lainnya untuk melihat apakah akan menambah tingkat akurasi pada proses klasifikasinya atau tidak.

\section{Daftar Pustaka}

[1] I. Gandjar and dkk, Mikologi Dasar dan Terapan, Jakarta: Yayasan Obor, 2006.

[2] A. Fadlil, "Sistem pengenalan citra jenis-jenis tekstil.," Jurnal Spektrum Industri. Yogyakarta : UAD., 2012.

[3] Y. Permadi and Murito, "Aplikasi Pengolahan Citra Untuk Identifikasi Kematangan Mentimun Berdasarkan Tekstur Kulit Buah Mentimun Menggunakan Metode Ekstraksi Ciri Statistik," Jurnal Informatika.Yogyakarta : UAD., 2015. 
[4] O. D. Nurhayati, "Sistem Analisis Tekstur Secara Statistik Orde Pertama Untuk Mengenali Jenis Telur Ayam Biasa Dan Telur Ayam Omega-3," Jurnal Sistem Komputer.UNDIP., 2015.

[5] c. Agrawal, Data Mining, New York: Springer, 2015.

[6] S. Gustina, A. Fadlil and R. Umar, "Sistem Identifikasi Jamur Menggunakan Metode Ciri Statistik Orde 1dan Klasifikasi Jarak," Teknologi Informasi, vol. 16, no. 4, 2017.

[7] A. Halim, H. Hardy and M. Mytosin, "Aplikasi Image Retrieval dengan Histogram Warna dan Multiscale GLCM," SIFO Mikroskil, vol. 16, no. 1, pp. 41-50, 2015.

[8] W. R. Gonzales, Digital Image Processing, United State,America.: Prentice-Hall, Inc., 2007.

[9] F. Liantoni and H. Nugroho, "Image Contrast Improvement With Equalization Histogram And Gaussian In Watermelon Classification," in Institut Teknologi Adhi Tama Surabaya., Surabaya, 2016.

[10] J. Han, M. Kamber and J. Pei, Data Mining Concepts and Techniques, Amerika: Elsevier Inc, 2012.

[11] Jiang, "Error estimation based on variance analysis of k-fold cross-validation.," Pattern Recognition, vol. Volume 69, no. September 2017, pp. 94-106, 2017.

[12] R. K. Hapsari, M. I. Utoyo, R. Rulaningtyas and H. Suprajitno, "Iris segmentation using Hough Transform method and Fuzzy C-Means method," Journal of Physics: Conference Series, vol. 1477, no. 2, 2020.

[13] A. S. Fitri, "Implementasi Ektraksi Ciri Statistik Untuk Identifikasi Kematangan Buah Berdasarkan Tekstur Kulit Buah," Simki-Techsain, Universitas Nusantara PGRI Kediri, 2016.

[14] Z. E. Rasjid and ReinaSetiawana, "Performance Comparison and Optimization of Text Document Classification using k-NN and Naïve Bayes Classification Techniques," in Procedia Computer Science, Bali, 2017. 